\title{
Seasonal species distribution and dominance in grazed Terai grassland of Budhanagar, Nepal
}

\author{
Bhabindra Niroula* and Sasinath Jha \\ Department of Botany \\ Post Graduate Campus, Tribhuvan University, Biratnagar, Nepal \\ *E-mail:niroulab@gmail.com
}

\begin{abstract}
Assessment of seasonal distribution and dominancy of herbaceous species of a grazed grassland of Budhanagar, eastern Terai region of Nepal was carried out in 2010. A total of 33 species: grasses (10), sedges (5), legumes (4) and non- legumes (14) were recorded with distinct seasonal occurrence. Most dominant species throughout the year were: Chrysopogon aciculatus (biomass 91.0-1720.5 g/m²; IVI 78.8-99.8 ); Desmodium triflorum (biomass $30-679.3 \mathrm{~g} / \mathrm{m}^{2}$; IVI 13.8-41.7) and Imperata cylindrical (biomass 12.0-83.3 $\mathrm{g} / \mathrm{m}^{2}$; IVI 20.7-34.6). Maximum total community biomass (3650.7 \pm 19.1 $\left.\mathrm{g} / \mathrm{m}^{2}\right)$ was recorded in rainy and minimum $\left(175.0 \pm 4.1 \mathrm{~g} / \mathrm{m}^{2}\right)$ in summer season. Maximum percent contribution by biomass and IVI of grasses was in winter season (90.3 and 76.2); sedges (17.1 and 19.0) and legume (12.6 and 15.0) in rainy season and that of non-legume in summer season (7.5 and 15.7) to the total community biomass and IVI, respectively.
\end{abstract}

Key words: Biomass, density, forbs, grasses, IVI, legumes.

\section{Introduction}

Grasslands are important in terms of biodiversity and sources of forage for domestic livestock. In the Terai plain of Nepal grasslands occur along flood plains and terraces. Cultivation and massive grazing has changed the species composition of palatable and native species. Heavy grazing has caused retrogression from bunchgrass dominant swards to prostrate, low-producing, grazing tolerant but nutrient-poor, allelochemic-rich grasses and forbs (Jha \& Jha, 2000; 2002; Jha, 2003).The grassland communities are being invaded by unpalatable species to cattle. On the other hand grasslands are continually being lost to agriculture, human settlements and urbanization. In this context, assessment of grassland quality is inevitable. This study is aimed to understand the seasonal distribution and dominancy of species in grazed grassland of Terai.

The study area (2.5 ha) is located in Budhnagar-5, Vediyari (Lat. $26^{\circ} 22^{\prime} \mathrm{N}$, Long $87^{\circ} 16^{\prime}$ E, Alt $72 \mathrm{msl}$ ) in eastern Terai plain of Nepal. The climate is tropical and monsoon. There are three distinct seasons in a year viz. rainy (July-October), winter (November-February) and summer (March-June). Soil is alluvial and loamy in texture (sand $40 \%$, silt $40 \%$ and clay $20 \%$. The average $\mathrm{pH}$ of the soil $(0-10 \mathrm{~cm}$ depth) is 6.5 . Average meteorological data indicate 1225,5 , and $188 \mathrm{~mm}$ rainfall; $25,10.4$ and $19.6^{\circ} \mathrm{C}$ minimum air temperature; $32.2,25$ and $33.6^{\circ} \mathrm{C}$ maximum air temperature; and $6,3.8$ and $6,3.8$ and $7.3 \mathrm{~km} / \mathrm{h}$ wind speed during rainy, winter and summer season, respectively for the last five years. The study area is fallow land subjected to heavy grazing by cows and buffaloes of different ages throughout the season. 


\section{Materials and Methods}

Ten quadrats of size $30 \mathrm{~cm} \times 30 \mathrm{~cm}$ were sampled in the grazed field during winter (January), summer (May) and rainy (September) seasons. Collected samples (live shoots and rhizomes) were washed and brought to the laboratory and after proper sorting and processing oven dried to a constant weight at $80^{\circ} \mathrm{C}$

Table 1. Seasonal occurrence of species in the study site (+ present, - absent).

\begin{tabular}{|c|c|c|c|c|c|}
\hline S.N. & Plant species & Family & Summer & Rainy & Winter \\
\hline & Monocotyledonae - Grasses & & & & \\
\hline 1. & Axonopus compressus (Swartz.) Beauv. & Poaceae & + & + & + \\
\hline 2. & Brachiaria villosa(Lam.) & Poaceae & - & - & + \\
\hline 3. & Chrysopogon aciculatus(Retz.)Trin. & Poaceae & + & + & + \\
\hline 4. & Cynodon dactylon(L.) Pers & Poaceae & + & + & + \\
\hline 5. & Dicanthium annulatum (Forsk.) Stapf. & Poaceae & + & + & + \\
\hline 6. & Hemarthria compressa (L. f) R. Br & Poaceae & + & + & - \\
\hline 7. & Imperata cylindrica (L.) Beauvois & Poaceae & + & + & + \\
\hline 8. & Paspalum distichum $\mathrm{L}$. & Poaceae & + & + & + \\
\hline 9. & Saccharum spontaneum $\mathrm{L}$. & Poaceae & + & + & + \\
\hline \multirow[t]{3}{*}{10.} & Settaria palludefusca (Scmach. Sapf \& & & & & \\
\hline & C.E. Hubbard & Poaceae & - & + & + \\
\hline & Monocotyledonae - Sedges & & & & \\
\hline 11. & Cyperus rotundus $\mathrm{L}$. & Cyperaceae & - & + & + \\
\hline 12. & Eriocaulon viridae Korn. & Cyperaceae & - & + & + \\
\hline 13. & Fimbristylis miliacea (L.) Vahl. & Cyperaceae & - & + & - \\
\hline 14. & Kyllinga brevifolia Rottb. & Cyperaceae & + & + & + \\
\hline \multirow[t]{2}{*}{15.} & Murdania nudiflora (L.) Brenan & Cyperaceae & & & \\
\hline & Dicotyledonae - Legumes & & & & \\
\hline 16. & Alysicarpus vaginalis (L.) DC. & Fabaceae & - & + & + \\
\hline 17. & Desmodium triflorum (L.) DC. & Fabaceae & + & + & + \\
\hline 18. & Indigofera linifolia (L. f) Retz. & Fabaceae & - & + & - \\
\hline \multirow[t]{2}{*}{19.} & Mimosa pudica (L.) Mukurjee & Fabaceae & + & + & \\
\hline & Dicotyledonae - Non legumes & & & & \\
\hline 20. & Ageratum conyzoides $\mathrm{L}$. & Asteraceae & - & - & + \\
\hline 21. & Centella asiatica (L.) Urb. & Apiaceae & - & + & + \\
\hline 22. & Euphorbia hirta L. & Euphorbiaceae & + & + & + \\
\hline 23. & Evolvulus nummularius L. & Convolvulaceae & + & + & + \\
\hline 24. & Hedyotis corymbosa (L.) Lam. & Rubiaceae & - & + & - \\
\hline 25. & Hemigraphis hirta (Vahl.) T. Anders & Acanthaceae & - & + & + \\
\hline 26. & Hygrophila polysperma (Roxb.)T.And & Acanthaceae & - & + & - \\
\hline 27. & Ixeris polycephala Cass. & Asteraceae & - & + & - \\
\hline 28. & Lindernia oppositifolia (L.) Mukurjee & Scrophulariaceae & - & + & - \\
\hline 29. & Parthenium hysterophorus L. & Asteraceae & + & + & + \\
\hline 30. & Phyllanthus amarus Schumacher & Euphorbiaceae & + & + & + \\
\hline 31. & Rungia parviflora (Retz.) Nees & Acanthaceae & + & - & + \\
\hline 32. & Solanum nigrum $\mathrm{L}$. & Solanaceae & + & + & + \\
\hline 33. & Veronia cinerea (L.) Lees & Asteraceae & + & - & - \\
\hline
\end{tabular}


Dominance was determined by phytosociological assessment of the samples (Zobel et al., 1987). Plant species were identified by standard literature (Siwakoti \& Varma, 1999). The identified species were cross checked with the specimens housed at the Tribhuvan University Regional Herbarium (TURH), Department of Botany, Post Graduate Campus, T.U., Biratnagar, Nepal.

Table 2. Seasonal range of frequency (\%), density (ind./ $\left.\mathrm{m}^{2}\right)$, biomass $\left(\mathrm{g} / \mathrm{m}^{2}\right)$ and IVI of major species (IVI >13) in the grazed grassland.

\begin{tabular}{lllll}
\hline species & Frequency $(\%)$ & Density $\left(\mathbf{I n d} . \mathbf{m}^{\mathbf{2}}\right)$ & Biomass $\left(\mathbf{g} / \mathbf{m}^{2}\right)$ & IVI \\
\hline Chrysopogon aciculatus & $90-100$ & $375.5-7749.2$ & $91.0-1720.5$ & $78.8-99.8$ \\
Desmodium triflorum & $80-100$ & $30.0-679.3$ & $30-679.3$ & $13.8-41.7$ \\
Imperata cylindrica & $90-100$ & $187.8-336.3$ & $12.0-83.3$ & $20.7-34.6$ \\
Dicanthium annulatum & $30-90$ & $42.2-128.8$ & $7.0-188.7$ & $11.5-34.7$ \\
Paspalum distichum & $90-100$ & $97.6-208.7$ & $15.0-299.7$ & $21.6-30.0$ \\
Evolvulus nummularius & $60-70$ & $45.5-114.4$ & $10.5-27.8$ & $7.6-23.6$ \\
Fimbristylis miliacea & $0-100$ & $0-218.7$ & $0-344.1$ & $0-24.0$ \\
Setaria paludefusca & $20-90$ & $6.7-305.2$ & $6.7-305.2$ & $3.3-19.9$ \\
Rungia pectinata & $0-90$ & $0-68.9$ & $2.2-21.6$ & $15.7-19.0$ \\
Hemarthria compressa & $0-100$ & $0-160$ & $0-18.0$ & $0-33.0$ \\
Cynodon dactylon & $0-70$ & $0-42.2$ & $1.6-66.7$ & $8.4-15.2$ \\
Axonopus compressus & 10 & $22.2-53.3$ & $6.4-88.8$ & $4.0-13.2$ \\
\hline
\end{tabular}

Table 3. Seasonal variation in biomass $\left(\mathrm{g} / \mathrm{m}^{2}\right)$ and IVI of different plant groups (figure in parenthesis represent percent value; \pm mean standard error).

\begin{tabular}{lllllll}
\hline \multirow{2}{*}{$\begin{array}{l}\text { Grassland } \\
\text { community }\end{array}$} & \multicolumn{5}{c}{ Biomass $\left(\mathbf{g} / \mathbf{m}^{\mathbf{2}}\right)$} & \multicolumn{3}{c}{ IVI } \\
\cline { 2 - 7 } & Winter & Summer & Rainy & Winter & Summer & Rainy \\
\hline Grasses & $157.6 \pm 3.9$ & $2511.5 \pm 15.8$ & $1718.4 \pm 13.1$ & $227.5 \pm 4.7$ & $164.7 \pm 4.0$ & $228.5 \pm 4.7$ \\
& $(90.1)$ & $(68.8)$ & $(90.3)$ & $(75.9)$ & $(54.9)$ & $(76.2)$ \\
\hline Sedges & $3.3 \pm 0.5$ & $623.3 \pm 7.8$ & $33.3 \pm 1.8$ & $11.5 \pm 1.0$ & $56.6 \pm 2.3$ & $9.0 \pm 0.9$ \\
& $(1.8)$ & $(17.1)$ & $(1.8)$ & $(3.8)$ & $(19.0)$ & $(3.1)$ \\
\hline Legumes & $1.0 \pm 0.3$ & $460.6 \pm 6.7$ & $111.3 \pm 3.3$ & $13.8 \pm 1.1$ & $45.4 \pm 2.1$ & $34.8 \pm 1.8$ \\
& $(0.6)$ & $(12.6)$ & $(5.8)$ & $(4.6)$ & $(15)$ & $(11.6)$ \\
\hline Non legumes & $13.1 \pm 1.1$ & $55.3 \pm 2.3$ & $39.9 \pm 1.9$ & $47.2 \pm 2.1$ & $33.3 \pm 1.8$ & $39.2 \pm 1.9$ \\
& $(7.5)$ & $(1.5)$ & $(2.1)$ & $(15.7)$ & $(11.1)$ & $(13.1)$ \\
\hline Total & $\mathbf{1 7 5 . 0} \pm \mathbf{4 . 1}$ & $\mathbf{3 6 5 0 . 7} \pm \mathbf{1 9 . 1}$ & $\mathbf{1 9 0 2 . 9 \pm 1 3 . 7}$ & $\mathbf{3 0 0} \pm \mathbf{5 . 4}$ & $\mathbf{3 0 0} \pm \mathbf{5 . 4}$ & $\mathbf{3 0 0} \pm \mathbf{5 . 4}$ \\
\hline
\end{tabular}




\section{Results and Discussion}

The grazed grassland had a total of 33 species/ genera and 12 families. Number of species recorded in the site was: grasses (10), sedges (5), legumes (4) and non legumes (14) with distinct seasonal distribution (Table 1). Jha and Jha (2000) recorded the presence of 31 species out of which 20 were graminoids, 2 legume and 9 non legume forbs in the grazed grassland of Terai plain. Number of species in rainy, winter and summer season was 24, 22 and 17, respectively. Sorrensen's similarity index (SI) of grassland species in rainy and winter season was maximum $(66.7 \%)$ while that with summer season was minimum $(48.6 \%)$ in the study site.

Dominant species were: Chrysopogon aciculatus (biomass range $91.0-1720.5 \mathrm{~g} / \mathrm{m}^{2}$ and IVI range 78.8-99.8), Imperata cylindrica (biomass range $12.0-83.3 \mathrm{~g} / \mathrm{m}^{2}$ and IVI range 20.7-34.6) Dicanthium annulatum (biomass range $7.0-188.7 \mathrm{~g} / \mathrm{m}^{2}$ and IVI range 11.5-34.7) among grasses; Desmodium triflorum (biomass range $30-679.3 \mathrm{~g} / \mathrm{m}^{2}$ and IVI range $13.8-41.7$ among legumes; Evolvulus numularius (biomass range $10.5-27.8 \mathrm{~g} / \mathrm{m}^{2}$ and IVI range $7.6-23.6$ among forbs; and Fimbristylis miliacea (biomass range $0-344.1 \mathrm{~g} / \mathrm{m}^{2}$ and IVI range $0-24.0$ among sedges (Table 2). However, there was dominancy of only few species in the grassland. Gaston (1994) opined that grassland communities are often represented by a small number of abundant species and a large number of low abundance or less frequent species.

Tsuchida (1983) reported five grassland community types (Dactyloctenium aegypticum, Chrysopogon aciculatus, Cynodon dactylon, Paspalum scrobiculatum and Cyperus rotundus types) below $1100 \mathrm{~m}$ altitude in eastern Nepal. Peet et al. (1991) have reported Sacchrum spontaneum assemblage in floodplain grasasland; Imperata cylindrical - Naregana porphyrocoma assemblage in newer river terraces, and Imperata cylindrica assemblage in previously cultivated dry sites with well developed soil. The study site from the value of biomass and IVI is recognized as Chrysopogon-Imperata-Desmodium community.

Almost all species of the summer were palatable to mild palatable to cattle in comparison to rainy and winter season. A comparison of the protected and grazed grassland in a semiarid region of Jhansi (Shankar et al., 1975) and Varanasi (Singh \& Mishra, 1969) indicated that the diversity, in general, increased in the grazed situation. Metera et al. (2010) reported that light grazing can be a tool to maintain or enhance biodiversity of grazed areas and contribute to the production of healthy food of high quality. Ageratum conyzoides, Euphorbia hirta, Ixeris polycephala, Parthenium hysterophorus, Solanum nigrum and Veronica cineria were unpalatable forbs. Dominance of grazing tolerant and allelochemic Chrysopogon aciculatus in the study site indicate over grazed situation.

Rainy season recorded maximum total community biomass $\left(3650.7 \pm 19.1 \mathrm{~g} / \mathrm{m}^{2}\right)$ and summer season minimum $\left(175.0 \pm 4.1 \mathrm{~g} / \mathrm{m}^{2}\right)$. Density, biomass and IVI in the grassland species closely paralleled the rainfall pattern and soil moisture. All the dominant species had prostrate growth forms with vegetative propagation in addition to sexual reproduction as reported earlier by Jha and Jha (2000) and Niroula and Mandal (2006). Seasonally, contribution to total community biomass and IVI by different community was variable. Maximum percent contribution by biomass and IVI of grasses was in winter season (90.3 and 76.2); sedges (17.1 and 19) and legume (12.6 and 15) in rainy season while that of non legume was in summer season (7.5\% and $15.7 \%)$ to the total community biomass and IVI, respectively. Sedges (1.8 and 3.8) and legumes (0.6 and 4.6) had least percent contribution in summer season while those of grasses 
(68.8 and 54.9) and non legumes (1.5 and 11.1) were in rainy season to the total community biomass and IVI respectively (Table 3).

In a grazing ecosystem, domestic and wild animals impact the primary producer compartment directly and other components indirectly such as decomposers, soil mineral cycling etc. indirectly (Shankar \& Singh, 1996). Output from the existing grassland can be enhanced through protection from overgrazing, appropriate management of defoliation, optimum soil hydration through accumulation of water conserving organic matter in soil, irrigation and application of fertilizers. Further, conservation and evaluation of native forage species for the better yield, quality, and persistence under various grazing management practices are also required for improving the pastures.

\section{Acknowledgement}

The first author is thankful to the Head, Department of Botany, Post Graduate Campus, Biratnagar, Tribhuvan University, Nepal for encouragements and providing laboratory facilities.

\section{References}

Gaston, K.J. 1994. Rarity. Chapman and hall, London. http://dx.doi.org/10.1007/978-94-011-0701-3

Jha, S. \& P.K. Jha. 2002. Allelopathic potential of some herbaceous forage species at Biratnagar, Nepal. Pakistan Journal of Plant Sciences 6(1): 33-42.

Jha, S. \& P.K. Jha. 2000. Seasonal changes in importance value index (IVI) and biomass in a lowland Nepalese grassland community. Geobios 27(1): 25-30.

Jha, S. 2003. Ecological study of some selected grasses and forbs found in Morang district of Nepal. Ph.D. Thesis, Tribhuvan University, Kathmandu.

Metera, E., T. Sakowski, K. Słoniewski \& B. Romanowicz. 2010. Grazing as a tool to maintain biodiversity of grassland- a review. Animal Science Papers and Reports 28 (4): 315-334.

Niroula, B. \& T.N. Mandal. 2006. Seasonal changes in species structure, diversity indices and plant biomass of a tropical grassland in eastern Nepal. In: Environment and Plants: Glimpses of Research in South Asia (Jha P.K., R.P. Chaudhary, S.B. karmacharya \& V. Prasad Eds.). Ecological society (ECOS), Kathmandu, Nepal. pp. 275-282.

Peet, N.B., A.R. Watkinson, D.J. Bell \& B.J. Kattel. 1991. Plant diversity in the threatened subtropical grasslands of Nepal. Biological conservation 88: 193-206.Chiba University. http://dx.doi.org/10.1016/S0006-3207(98)00104-9

Shankar, V. \& J.P. Singh. 1996. Gazing ecology. Tropical Ecology 37 (1): 67-78.

Shankar, V., K.C. Velayudhan \& B.K. Trivedi. 1975. Diversity, dominance, stability and net production in three communities of Sehima-Dicanthium cover. Geobios 2: 107-110.

Singh, J.S. \& R. Misra. 1969. Diversity, dominance, stability and net production in grasslands at Varanasi, India. Canadian Journal of Botany 47: 425-427. http://dx.doi.org/10.1139/b69-058

Siwakoti, M. \& S.K. Varma. 1999. Plant diversity of eastern Nepal/Flora of plains of eastern Nepal. Singh B. \& M.P. Singh. Dehra Dun (India). 491p.

Tsuchida, K. 1983. Grassland vegetation and succession in eastern Nepal. In: Structure and Dynamics of Vegetation in Eastern Nepal (Numata M. Ed.). Laboratory of Ecology, Chiba University, Chiba. pp. 47-88.

Zobel, D.B., P.K. Jha, U.K. Yadav \& M.J. Behan. 1987. A practical manual of ecology. Kathmandu, Ratna Book Distributors. 149p. 